\title{
Peningkatan Hasil Belajar Matematika Siswa Kelas V dalam Operasi Hitung Bilangan Bulat dengan Menggunakan Media Kartu Pasangan Warna di SDN. No. 040/XI Koto Limau Manis
}

\author{
Elmiati $^{1}$ \\ Guru di SDN. No.040/XI Koto Limau Manis ${ }^{1}$ \\ Kecamatan Koto Baru, Kota Sungai Penuh, Provinsi Jambi
}

\begin{abstract}
This classroom action research was conducted to improve students' learning outcomes in mathematic subject, especially on the subject matter of integer counting using the color pair card media. This research was conducted for six months from June to November of 2016. This research involves all fifth grade students year 2016/2017 at SDN No.040/XI Koto Limau Manis which are 15 students. This research activity is carried out in two cycles. Each cycle consists of two meetings and four activities namely planning, implementation, observation, and reflection. Evaluation of student learning outcomes using test and observation. The data that have been collected is analyzed by descriptive analysis and simple statistical test. The results showed that the use of media allows students to understand math lessons, especially material counting integer operations. In addition, the use of media also makes students feel happy and eager to learn, as well as increasing the courage of students to appear in front of the class. Improvement also occurs in terms of student learning outcomes. The average grade value that initially 44 increased to 70 after the implementation of cycle I and again increased to 76 after the implementation of cycle II. The average grade value after the given action is higher than the value at which action has not been given. Student learning mastery also increased from $33.3 \%$ (pratindakan) to $80.0 \%$ (cycle I) and $93.0 \%$ (cycle II).
\end{abstract}

Keywords: color pair card, integer counting, learning outcome, mathematic subject

\section{PENDAHULUAN}

Matematika merupakan ilmu universal yang mendasari perkembangan teknologi modern, mempunyai peran penting dalam berbagai disiplin, dan memajukan daya pikir manusia. Perkembangan pesat di bidang teknologi informasi dan komunikasi dewasa ini dilandasi oleh perkembangan matematika di bidang teori bilangan, aljabar, analisis, teori peluang, dan matematika diskrit. Untuk menguasai dan mencipta teknologi di masa depan diperlukan penguasaan matematika yang kuat sejak dini.

Mata pelajaran Matematika perlu diberikan kepada semua peserta didik mulai dari sekolah dasar untuk membekali peserta didik dengan kemampuan berpikir logis, analitis, sistematis, kritis, dan kreatif, serta kemampuan bekerjasama. Kompetensi tersebut diperlukan agar peserta didik dapat memiliki kemampuan memperoleh, mengelola, dan memanfaatkan informasi untuk bertahan hidup pada keadaan yang selalu berubah, tidak pasti, dan kompetitif. Dalam setiap kesempatan, pembelajaran matematika hendaknya dimulai dengan pengenalan masalah yang sesuai dengan situasi. Dengan mengajukan masalah kontekstual, siswa secara bertahap dibimbing untuk menguasai konsep matematika. Untuk meningkatkan keefektifan pembelajaran, sekolah diharapkan menggunakan media dalam kegiatan pembelajaran.

Konsep dasar matematika harus dikuasai secara tuntas mulai dari Sekolah Dasar. Akan tetapi, masih banyak kendala yang dihadapi, diantaranya adalah pengajaran metematika dirasakan sulit di segala jenjang pendidikan. Siswa sering mengeluh bahwa pelajaran matematika 
membosankan, tidak menarik, bahkan penuh misteri. Hal ini disebabkan karena pelajaran matematika dirasakan sukar, gersang, dan tidak tampak kaitannya dengan kehidupan sehari-hari. Hasil Training Need Assessment (TNA) atau "pengukuran kebutuhan diklat" yang dilakukan oleh Pusat Pengembangan dan Pemberdayaan Pendidik dan Tenaga Kependidikan Matematika pada kurun waktu 2004 hingga 2009 menunjukkan bahwa bilangan bulat beserta operasinya termasuk materi pembelajaran yang masih dianggap sulit bagi guru (Raharjo \& Sumardi 2010).

Zulkardi (2003), diacu dalam Supardi (2012) menyatakan bahwa hasil belajar matematika siswa yang rendah disebabkan oleh banyak hal, seperti: kurikulum yang padat, media belajar yang kurang efektif, strategi dan metode pembelajaran yang dipilih oleh guru kurang tepat, sistem evaluasi yang buruk, kemampuan guru yang kurang dapat membangkitkan motivasi belajar siswa, atau juga karena pendekatan pembelajaran yang masih bersifat konvensional sehingga siswa tidak banyak terlibat dalam proses pembelajaran.Masalah lain yang juga menghambat penguasaan siswa dalam pembelajaran matematika adalah daya ingat yang rendah terhadap konsep matematika yang telah diajarkan. Setelah pembelajaran, siswa dapat memahami atau mengerjakan soal-soal yang diberikan oleh guru. Akan tetapi, beberapa hari kemudian, siswa tidak dapat menyelesaikan soal yang sama dengan benar, apalagi beberapa bulan atau beberapa tahun yang akan datang. Kondisi ini akan diperparah dengan semakin kompleksnya beban materi yang harus dikuasai siswa seiring dengan meningkatnya tingkatan kelas yang ditempati siswa.

Penguasaan dalam pembelajaran matematika yang masih rendah juga terjadi pada siswa kelas V SDN. No.040/XI Koto Limau Manis tahun pelajaran 2016/2017. Siswa mengalami kesulitan dalam menguasai materi operasi penjumlahan dan pengurangan bilangan bulat. Nilai yang diperoleh siswa pada materi itu amat rendah. Berdasarkan hasil tes penjajakan yang dilakukan terhadap 15 orang siswa, rata-rata nilai perolehan siswa yang diperoleh hanya 44. Hasil penjajakan menunjukkan bahwa 2orang siswa memperoleh nilai 7,3 orang siswa memperoleh nilai 6,1 orang siswa memperoleh nilai 5, 4orang siswa memperoleh nilai 4, 3orang siswa memperoleh nilai 3 , dan 1 orang siswa memperoleh nilai 2. Padahal, materi penjumlahan dan pengurangan bilangan bulat (bilangan bulat positif dan bilangan bulat negatif) sudah diajarkan di kelas IV. Pemahaman siswa yang rendah tentang konsep penjumlahan dan pengurangan bilangan bulat khususnya bilangan bulat negatif merupakan masalah rutin yang ditemukan peneliti selama lima tahun mengajar di kelas V. Masalah ini masih belum menemukan solusinya.

Rendahnya hasil belajar siswa menunjukkan adanya kesenjangan dalam prestasi akademik yang menjadi patokan untuk mengukur keberhasilan atau kegagalan siswa dalam belajar. Kesenjangan antara prestasi akademik yang diharapkan dengan prestasi akademik yang dicapai menunjukkan adanya masalah dalam kegiatan pembelajaran yaitu masalah kesulitan belajar (Irham dan Wiyani, 2016). Siswa yang berhasil dalam belajar akan menunjukkan prestasi bagus dalam bentuk penguasaan terhadap bahan dan materi pelajaran yang diberikan oleh guru yang dapat dilihat dari tingginya perolehan nilai ujian atau hasil evaluasi yang dicapai. Sebaliknya, siswa yang belum berhasil dan mengalami kesulitan dalam menguasai materi pelajaran akan ditandai dengan rendahnya nilai ujian yang diperoleh.

Kesulitan belajar merupakan masalah yang dihadapi oleh siswa yang menyebabkan siswa tersebut tidak dapat mengikuti proses pembelajaran dengan 
baik sehingga ia tidak bisa mencapai tujuan belajar yang diharapkan (Irham \& Wiyani, 2016). Kesulitan belajar dipengaruhi oleh 2 (dua) faktor yaitu:

a. Faktor internal. Faktor internal yang dapat menyebabkan kesulitan belajar bagi siswa antara lain: kemampuan intelektual, perasaan dan kepercayaan diri, motivasi, kematangan untuk belajar, usia, jenis kelamin, kebiasaan belajar, kemampuan mengingat, serta kemampuan mengindra seperti melihat, mendengarkan, membau, dan merasakan.

b. Faktor eksternal. Faktor eksternal yang dapat menyebabkan kesulitan belajar bagi siswa dapat berupa guru, kualitas pembelajaran, instrumen dan fasilitas pembelajaran, serta lingkungan sosial dan alam.

Apabila masalah yang terjadi di SDN. No.040/XI Koto Limau Manis diteliti lebih mendalam, pemahaman siswa yang rendah terhadap materi operasi hitung bilangan bulat khususnya penjumlahan dan pengurangan bilangan bulat yang melibatkan bilangan bulat negatif tidak hanya disebabkan dari pihak siswa saja, namun juga dari pihak guru sendiri. Salah satu penyebabnya adalah guru tidak dapat menyampaikan konsep yang abstrak menjadi kongkrit dan mudah dipahami oleh siswa. Hal ini sebagai akibat dari cara mengajar guru yang monoton danjuga penggunaan media pembelajaran yang kurang tepat. Selama ini, banyak guru yang beranggapan bahwa media pembelajaran yang baik adalah media pembelajaran yang mahal, padahal tidak selalu seperti itu. Guru dapat memanfaatkan benda-benda yang ada di lingkungan sekitar sebagai media pembelajaran.

Media pembelajaran merupakan alat dan bahan yang membawa informasi atau bahan pelajaran yang bertujuan untuk mempermudah mencapai tujuan pembelajaran. Media pembelajaran ini berperan penting dalam keberhasilan pembelajaran karena media pembelajaran dapat berfungsi sebagai penarik perhatian siswa, memberikan motivasi siswa untuk belajar, menumbuhkan kesadaran emosi dan sikap siswa terhadap materi dan orang lain, mengakomodasi siswa yang lemah dalam menerima dan memahami pelajaran yang disajikan dalam bentuk teks dan verbal, mengakomodasikan siswa untuk melakukan suatu kegiatan secara motorik, dan mampu menilai kemampuan siswa dalam merespons pembelajaran.

Selama ini, media pembelajaran yang digunakan dalam operasi hitung bilangan bulat di SD. No. 040/XI Koto Limau Manis adalah garis bilangan. Penggunaan garis bilangan sebagai media pembelajaran pada materi penjumlahan dan pengurangan bilangan bulat dirasakan belum cukup efektif untuk menigkatkan pemahaman siswa. Keterbatasan dari media garis bilangan adalah keterbatasan angka. Media ini sulit untuk melakukan operasi penjumlahan dan pengurangan bilangan yang lebih besar dari sepuluh dan kecil dari negatif sepuluh. Jika masalah rendahnya pemahaman siswa dalam konsep penjumlahan dan pengurangan bilangan bulat dibiarkan berlanjut akan berakibat pada terhambatnya penguasaan siswa pada konsep matematika yang lebih rumit. Hasil belajar siswa mengenai konsep matematika lain yang lebih kompleks akan tetap rendah. Selain itu, anggapan matematika sebagai mata pelajaran yang menakutkan dan sulit tidak akan pernah hilang.

Pembelajaran penjumlahan dan pengurangan bilangan bulat positif hampir tidak menjadi masalah di Kelas V SDN. No. 040/XI Koto Limau Manis. Namun, siswa mulai merasa kesulitan apabila penjumlahan dan pengurangan yang melibatkan bilangan bulat negatif. Oleh sebab itu, guru mencoba memecahkan masalah ini dengan memanfaatkan media pembelajaran. Menurut Arsyad (2009), penggunaan media dalam kegiatan pembelajaran dapat memperjelas penyajian pesan yang ingin disampaikan oleh pendidik, mengatasi keterbatasan ruang, 
waktu dan daya indera, mengatasi sikap pasif anak didik, menyamakan pengalaman dan persepsi peserta didik terhadap isi pelajaran, serta memberikan kesamaan pengalaman kepada peserta didik. Media pembelajaran yang tepat. Sukayati dan Suharjana (2009) menambahkan bahwa pemilihan media yang tepat dan digunakan secara benar diharapkan dapat mempermudah abstraksi, memudahkan, memperbaiki, atau meningkatkan penguasaan konsep atau fakta, memberikan motivasi, memberikan variasi pembelajaran, meningkatkan efisiensi waktu, dan meningkatkan keterlibatan peserta didik dalam pembelajaran.Salah satu media yang dapat digunakan untuk meningkatkan pemahaman siswa dalam penjumlahan dan pengurangan bilangan bulat adalah kartu pasangan warna.

Penjumlahan dan pengurangan bilangan bulat merupakan konsep dasar yang harus dikuasai oleh siswa pada mata pelajaran matematika. Untuk memudahkan siswa menguasai konsep tersebut maka diperlukan media pembelajaran yang relevan, salah satunya adalah penggunaan kartu pasangan warna. Penggunaan media ini diharapkan dapat membantu siswa dalam memahami konsep operasi hitung bilangan bulat. Khususnya dalam hal penjumlahan dan pengurangan bilangan bulat. Alasan inilah yang mendorong peneliti untuk melakukan penelitian tindakan kelas yang berjudul "Peningkatan Hasil Belajar Matematika Siswa Kelas V dalam Operasi Hitung Bilangan Bulat Melalui Penggunaan Media Kartu Pasangan Warna di SDN. No. 040/XI Koto Limau Manis". Penelitian ini bertujuan untuk meningkatkan hasil belajar siswa kelas V SDN. No. 040/XI Koto Limau Manis pada mata materi penjumlahan dan pengurangan bilangan bulat hingga dengan menggunakan media kartu pasangan warna. Dengan mengunakan media kartu pasangan warna, peneliti berharap hasil belajar siswa dapat mencapai Kriteria
Ketuntasan Minimum yang telah ditetapkan.

\section{METODE PENELITIAN}

Penelitian yang dilakukan merupakan penelitian tindakan kelas. Kegiatan penelitian dilakukan di kelas V SDN. No.040/XI Koto Limau Manis, Kecamatan Koto Baru, Kota Sungai Penuh, Provinsi Jambi. Secara umum, kegiatan penelitian terdiri atas persiapan penelitian, pelaksanaan penelitian, dan pelaporan hasil penelitian. Waktu yang dibutuhkan untuk melakukan kegiatan penelitian adalah 6 (enam) bulan yaitu sejak bulan Juni sampai dengan bulan November tahun 2016.

Peneliti merupakan guru di kelas $\mathrm{V}$ SDN No.040/XI Koto Limau Manis. Penelitian tindakan kelas ini diset untuk siswa kelas V SDN No.040/XI Koto Limau Manis yang diselenggarakan pada semester ganjil tahun akademik 2016/2017. Oleh karena itu, subjek dari penelitian ini adalah siswa kelas V SDN No. 040/XI Koto Limau Manis. Subjek penelitian berjumlah 15 orang siswa yang terdiri atas 7 orang siswa laki-laki dan 8 orang siswa perempuan.

Ada dua alat evaluasi hasil belajar yang digunakan dalam penelitian ini yaitu evaluasi hasil belajar jenis tes dan nontes. Tes merupakan serangkaian aktivitas yang harus dikerjakan oleh siswa, baik secara individu atau kelompok untuk melihat kemampuan siswa atau kelompok tersebut. Guru memberikan tes pada siswa. Setelah itu, guru melakukan penilaian terhadap hasil tes. Hasil tes yang diperoleh dibandingkan dengan Kriteria Ketuntasan Minimum (KKM). Selanjutnya, evaluasi hasil belajar jenis nontes dilakukan dengan cara observasi (pengamatan). Pengamatan atau observasi adalah suatu teknik yang dilakukan dengan cara mengadakan pengamatan secara teliti serta pencatatan secara sistematis. Data yang telah dikumpulkan selanjutnya diolah dan dianalisis. Pada penelitian ini, data 
dianalisis menggunakan analisis deskriptif dan uji statistik sederhana.

Kegiatan penelitian dilakukan dalam dua siklus (Siklus I dan Siklus II) yang mana setiap siklus dilaksanakan dalam dua kali tatap muka. Ada empat kegiatan yang dilakukan pada setiap siklus, yaitu: Perencanaan, Pelaksanaan, Pengamatan, dan Refleksi. Indikator keberhasilan dari penelitian tindakan kelas ini adalah meningkatnya hasil belajar matematika siswa kelas V SD.No.040/XI Koto Limau Manis yang mengacu kepada kriteria ketuntasan minimum (KKM) mata pelajaran yang telah ditentukan oleh sekolah di awal tahun pelajaran 2016/2017 yaitu: 60 .

\section{HASIL DAN PEMBAHASAN Hasil Pre-test}

Sebelum diberikan tindakan, siswa mengikuti pre-test. Tes ini bertujuan untuk melihat kemampuan awal siswa dalam penjumlahan dan pengurangan bilangan bulat.Cara yang ditempuh adalah dengan memberikan soal tes yang melibatkan penjumlahan dan pengurangan bilangan bulat positif dan negatif. Hasil tes penjajakan disajikan pada Tabel 1. Hasil penelitian menunjukkan bahwa nilai ratarata kelas yang diperoleh sebesar 44 yang mana nilai tersebut belum memenuhi Kriteria Ketuntasan Minimum (KKM) untuk mata pelajaran matematika yaitu 60 . Hasil ini juga mengindikasikan bahwa pembelajaran matematika tentang penjumlahan dan pengurangan bilanagan bulat di kelas IV belum berhasil. Hasil inilah yang mendasari pelaksanaan penelitian tindakan kelas ini.

Tabel 1 Hasil Pre-Test

\begin{tabular}{ccccc}
\hline No & Nilai & Frekuensi & Jumlah nilai & Jumlah Siswa \\
\hline 1 & 100 & - & - & 15 \\
2 & 90 & - & - & \\
3 & 80 & - & - & \\
4 & 70 & 2 & 140 & \\
5 & 60 & 3 & 180 & \\
6 & 50 & 1 & 50 & \\
7 & 40 & 4 & 160 & \\
8 & 30 & 2 & 90 & \\
9 & 20 & - & 40 & \\
10 & 10 & & - & \\
Jumlah & & & 660 & \\
Rata-Rata & & & $33,3 \%$ & \\
Ketuntasan belajar & &
\end{tabular}

\section{Hasil Penelitian Siklus I}

Siklus I dilaksanakan dalam 2 kali pertemuan yaitu pada hari selasa tanggal 23 Juli 2016 dan hari kamis tanggal 25 Juli 2016. Materi yang dibahas dalam dua pertemuan ini adalah penjumlahan bilangan bulan yang terdiri atas: (1) Penjumlahan bilangan bulat positf dengan bilangan bulat positif, (2) Penjumlahan bilangan bulat positif dengan bilangan bulat negatif, (3) Penjumlahan bilangan bulat negatif dengan bilagan bulat positif, dan (4) Penjumlahan bilangan bulat negatif dengan bilangan bulat negatif. Untuk melihat keberhasilan penerapan tindakan siklus I, guru melakukan evaluasi hasil belajar pada pada tanggal 30 Juli 2016.

Kegiatan yang dilakukan pada siklus I terdiri atas perencanaan, pelaksanaan, pengamatan, dan penutup. Pertama, Perencanaan. Langkah-langkah dalam kegiatan perencanaan adalah sebagai berikut: memilih bahan ajar yang diambil dari buku sumber, menyiapkan media, 
memilih dan menetapkan metode pembelajaran, merancang skenario/langkah-langkah pembelajaran, menyiapkan lembar kerja siswa, menyiapkan lembar observasi, dan menyiapkan butir soal untuk evaluasi kegiatan.

Kedua, Pelaksanaan. Pelaksanaan kegiatan penelitian dilakukan dalam tiga tahapan yaitu kegiatan pendahuluan, kegiatan inti, dan kegiatan akhir. Rincian kegiatan sebagai berikut: pendahuluan, inti, dan penutup.Kegiatan pendahuluan, terdiri atas: guru mengucapkan salam, guru membuka pelajaran dengan menyapa dan menanyakan kabar siswa, guru memeriksa kehadiran siswa, guru melakukan apersepsi, dan guru menyampaikan tema dan tujuan pembelajaran yang akan dicapai. Kegiatan inti, terdiri atas: guru membagikan fotocopy materi pembelajaran, guru menjelaskan materi pembelajaran, guru memeragakan cara menjumlahkan bilangan bulat positif dan negatif dengan menggunakan kartu pasangan warna, siswa menyimak penjelasan guru, guru memberikan kesempatan kepada siswa untuk mengemukakan pertanyaan, guru mengelompokkan siswa menjadi 3 (tiga) kelompok yang heterogen, guru memberi tugas kepada siswa untuk dikerjakan secara berkelompok, siswa mengerjakan tugas yang diberikan secara berkelompok dan memastikan setiap anggota kelompok dapat mengerjakan tugas tersebut, membimbing siswa yang belum dapat menyelesaikan latihan dengan benar dengan berkunjung dari bangku satu ke bangku lain, guru memanggil salah satu nomor siswa dan nomor yang dipanggil menyampaikan hasil kerja kelompoknya, siswa yang lain menanggapi hasil kerja kelompok yang sudah disampaikan, guru memanggil nomor lain untuk menyampaikan hasil kerja kelompoknya. Kegiatan akhir, terdiri atas: guru membimbing siswa dalam membuat kesimpulan, guru memberi kesempatan kepada beberapa siswa untuk menyampaikan pendapatnya tentang pembelajaran yang telah diikuti, guru melakukan evaluasi, guru memberi gambaran pembelajaran berikutnya, guru menyampaikan pesan moral, dan guru menutup kegiatan pembelajaran.

Ketiga, Pengamatan. Selama kegiatan pembelajaran berlangsung, ada beberapa catatan penting yang perlu diperhatian, baik berkaitan dengan proses pembelajaran maupun berkaitan dengan kegiatan guru dan siswa. Hasil pengamatan siswa pada Siklus I disajikan pada Tabel 2. Secara umum, hasil pengamatan sebagai berikut: kegiatan pembelajaran berlangsung biasa-biasa saja, jumlah kartu yang tersedia terbatas sehingga penggunaannya tidak optimal, hanya sebagian siswa aktif memanipulasi kartupasangan warna dalam menyelesaikan soal latihan, masih ada siswa yang tidak berani menyampaikan hasil tugas di depan kelas, sebanyak 33,0\% siswa masih belum memiliki media, siswa masih binggung menggunakan media dalam menyelesaikan soal, dan pengelolaan waktu masih kurang efektif.

Tabel 2 Hasil pengamatan aktivitas siswa pada Siklus I

\begin{tabular}{|c|c|c|c|}
\hline No & Kriteria & Jumlah & Persentase \\
\hline 1 & Siswa yang aktif & 10 & $67,0 \%$ \\
\hline 2 & Siswa yang memiliki media & 10 & $67,0 \%$ \\
\hline 3 & Siswa yang belum memiliki media & 5 & $33,0 \%$ \\
\hline 4 & Siswa yang dapat menggunakan media & 7 & $47,0 \%$ \\
\hline 5 & Siswa yang berani melaporkan hasil diskusi & 8 & $53,0 \%$ \\
\hline
\end{tabular}


Hasil pengamatan pada Tabel 2 menggambarkanadanya kemajuan yang cukup berarti dalam kegiatan pembelajaran. Hal ini terlihat dari adanya peran dan kepedulian siswa selama proses pembelajaran berlangsung yakni $67,0 \%$ siswa aktif dalam kegiatan pembelajaran dan 53,0\% siswa sudah berani melaporkan hasil diskusi. Walaupun harus diakui masih ada kekurangan yang perlu diperbaiki seperti $33,0 \%$ siswa belum memiliki media sehingga mereka cenderung mengganggu temannya karena adanya interaksi pinjam meminjam diantara mereka. Selain itu, hanya $47,0 \%$ siswa yang dapat mengoperasikan media. Dengan demikian proses, pembelajaran menggunakan media kartupasangan warna pada materi pembelajaran berikutnya masih perlu perbaikan supaya kesalahan yang sama tidak terulang kembali. Agar terlihat sinkronisasi antara keberhasilan di segi proses dengan keberhasilan di segi hasil atau prestasi belajar siswa, Hasil belajar siswa pada akhir Siklus I disajikan pada Tabel 3.

Tabel 3 Hasil belajar siswa pada akhir Siklus I

\begin{tabular}{cccccc}
\hline No & Nilai & Frekuensi & Skor & Jumlah nilai & $\sum$ Siswa \\
\hline 1 & 10 & 1 & 10 & 100 & 15 \\
2 & 9 & 1 & 10 & 90 & \\
3 & 8 & 4 & 10 & 320 & \\
4 & 7 & 4 & 10 & 280 & \\
5 & 6 & 2 & 10 & 120 & \\
6 & 5 & 2 & 10 & 100 & \\
7 & 4 & 1 & 10 & 40 & - \\
8 & 3 & - & 10 & - & \\
9 & 2 & - & 10 & - & \\
10 & 1 & - & 10 & 1050 & \\
Jumlah & & & & $80,0 \%$ & \\
Rata-rata & & & & & \\
Ketuntasan belajar & & & &
\end{tabular}

Berdasarkan data yang disajikan pada Tabel 3, diketahui bahwa nilai ratarata kelas yang diperoleh di akhir siklus I adalah 70,0. Nilai ini lebih besar dibandingkan dengan nilai rata-rata kelas saat tes penjajakan (pratindakan) yaitu 44 . Peningkatan nilai rata-rata kelas sekitar 26 point. Selain itu, informasi lain yang diperoleh dari Tabel 3 adalah capaian ketuntasan belajar siswa. Ketuntasan belajar siswa pada akhir siklus I adalah $80,0 \%$. Hasil yang diperoleh ini juga menunjukkan terjadinya peningkatan capaian ketuntasan belajar siswa dibandingkan dengan ketuntasan belajar siswa saat tes penjajakan (pratindakan) yaitu sebesar $33,3 \%$. Peningkatan yang terjadi sebesar $46,7 \%$. Berdasarkan hasil tersebut, dapat disimpulkan bahwa pemanfaatan media pembelajaran berupa kartu pasangan warna berhasil meningkatkan hasil belajar siswa dalam penjumlahan bilangan bulat: penjumlahan bilangan bulat positf dengan bilangan bulat positif, (2) penjumlahan bilangan bulat positif dengan bilangan bulat negatif, (3) penjumlahan bilangan bulat negatif dengan bilagan bulat positif, dan (4) penjumlahan bilangan bulat negatif dengan bilangan bulat negatif.

Keempat, Refleksi. Refleksi dari hasil penelitian adalah sebagai berikut: melaksanakan kegiatan pembelajaran yang melibatkan keaktifan seluruh siswa, mengoptimalkan penggunaan kartu pasangan warna, memotivasi siswa agar berani menyampaikan hasil diskusi kedepan kelas, mewajibkan setip siswa 
memiliki media pada kegiatan pembelajaran siklus II, dan merumuskan tindakan siklus II berdasarkan temuan pada siklus I.

\section{Hasil Penelitian Siklus II}

Siklus II dilaksanakan dalam 2 kali pertemuan yaitu pada hari selasa tanggal 20 Agustus 2016 dan hari kamis tanggal 22 Agustus 2016. Materi yang dibahas dalam dua pertemuan ini adalah pengurangan bilangan bulat yang terdiri atas: (1) Pengurangan bilangan bulat positf dengan bilangan bulat positif, (2) Pengurangan bilangan bulat positif dengan bilangan bulat negatif, (3) Pengurangan bilangan bulat negatif dengan bilagan bulat positif, dan (4) Pengurangan bilangan bulat negatif dengan bilangan bulat negatif. Untuk melihat keberhasilan penerapan tindakan siklus II, guru melakukan evaluasi hasil belajar pada pada tanggal 27Agustus 2016.

Kegiatan yang dilakukan pada siklus II terdiri atas perencanaan, pelaksanaan, pengamatan, dan penutup. Pertama, Perencanaan. Langkah-langkah dalam kegiatan perencanaan adalah sebagai berikut: memilih bahan ajar yang diambil dari buku sumber, menyiapkan media, memilih dan menetapkan metode pembelajaran, merancang skenario/langkah-langkah pembelajaran, menyiapkan lembar kerja siswa, menyiapkan lembar observasi, dan menyiapkan butir soal untuk evaluasi kegiatan.

Kedua, Pelaksanaan. Pelaksanaan kegiatan penelitian dilakukan dalam tiga tahapan yaitu kegiatan pendahuluan, kegiatan inti, dan kegiatan akhir. Rincian kegiatan sebagai berikut: pendahuluan, inti, dan penutup.Kegiatan pendahuluan, terdiri atas: guru mengucapkan salam, guru membuka pelajaran dengan menyapa dan menanyakan kabar siswa, guru memeriksa kehadiran siswa, guru melakukan apersepsi, dan guru menyampaikan tema dan tujuan pembelajaran yang akan dicapai. Kegiatan inti, terdiri atas: guru membagikan fotocopy materi pembelajaran, guru menjelaskan materi pembelajaran, guru memeragakan cara menjumlahkan bilangan bulat positif dan negatif dengan menggunakan kartu pasangan warna, siswa menyimak penjelasan guru, guru memberikan kesempatan kepada siswa untuk mengemukakan pertanyaan, guru mengelompokkan siswa menjadi 3 (tiga) kelompok yang heterogen, guru memberi tugas kepada siswa untuk dikerjakan secara berkelompok, siswa mengerjakan tugas yang diberikan secara berkelompok dan memastikan setiap anggota kelompok dapat mengerjakan tugas tersebut, membimbing siswa yang belum dapat menyelesaikan latihan dengan benar dengan berkunjung dari bangku satu ke bangku lain, guru memanggil salah satu nomor siswa dan nomor yang dipanggil menyampaikan hasil kerja kelompoknya, siswa yang lain menanggapi hasil kerja kelompok yang sudah disampaikan, guru memanggil nomor lain untuk menyampaikan hasil kerja kelompoknya. Kegiatan akhir, terdiri atas: guru membimbing siswa dalam membuat kesimpulan, guru memberi kesempatan kepada beberapa siswa untuk menyampaikan pendapatnya tentang pembelajaran yang telah diikuti, guru melakukan evaluasi, guru memberi gambaran pembelajaran berikutnya, guru menyampaikan pesan moral, dan guru menutup kegiatan pembelajaran.

Ketiga, Pengamatan.

Hasil pengamatan memperlihatkan bahwa proses pembelajaran hampir sempurna. Hal ini ditandai dengan kepiawaian guru dalam mengelola pembelajaran. Guru dapat menstimulasi aktivitas siswa, seperti aktif memanipulasi media dalam proses pembelajaran hingga 80,0\% dibandingkan dengan siklus I yang hanya sebesar $47,0 \%$. Begitu juga dengan partisipasi siswa di bidang lain seperti $73,0 \%$ siswa sudah berani melaporkan hasil diskusi di depan kelas. Hasil ini meningkat dibandingkan 
dengan siklus I yang hanya 53,0\%. Selain itu kesiapan siswa menghadapi pembelajaran mencapai $100,0 \%$. Hal ini ditandai dengan semua siswa telah menyiapkan media, sehingga pembelajaran berlangsung dengan menyenangkan, tanpa adanya gangguan dan kendala yang berarti baik dari pihak guru maupun dari pihak siswa. Selain itu, sebanyak $80,0 \%$ siswa juga sudah dapat mengoperasikan kartupasangan warna dengan baik dan benar. Hasil pengamatan aktivitas siswa pada Siklus II disajikan pada Tabel 4.

Secara umum, hasil pengamatan adalah sebagai berikut: Pelaksanaan siklus II berjalan sesuai rencana dan nyaris sempurna, aktivitas siswa lebih meningkat dari siklus sebelumnya, kerja siswa dalam kelompok kompak dan saling membantu, semua siswa telah memiliki media kartu pasangan warna, dan pembelajaran berlangsung dalam suasana gembira dan menyenangkan

Tabel 4 Hasil pengamatan aktivitas siswa pada Siklus II

\begin{tabular}{|c|c|c|c|}
\hline No & Kriteria & Jumlah & Persentase \\
\hline 1 & Siswa yang aktif & 12 & $80,0 \%$ \\
\hline 2 & Siswa yang memiliki media & 15 & $100,0 \%$ \\
\hline 3 & Siswa yang belum memiliki media & 0 & $0,0 \%$ \\
\hline 4 & Siswa yang dapat menggunakan media & 12 & $80,0 \%$ \\
\hline 5 & Siswa yang berani melaporkan hasil diskusi & 11 & $73,0 \%$ \\
\hline
\end{tabular}

Pelaksanaan tindakan pada siklus II
tidak hanya memperbaiki proses pembelajaran saja, namun juga meningkatkan hasil belajar siswa. Hasil belajar siswa pada akhir siklus II disajikan pada Tabel 5.

Tabel 5 Hasil belajar siswa pada Siklus II

\begin{tabular}{cccccc}
\hline No & Nilai & Frekuensi & Skor & Jumlah Nilai & $\sum$ Siswa \\
\hline 1 & 10 & 2 & 10 & 200 & 15 \\
2 & 9 & 1 & 10 & 90 & \\
3 & 8 & 5 & 10 & 400 & \\
4 & 7 & 4 & 10 & 280 & \\
5 & 6 & 2 & 10 & 120 & \\
6 & 5 & 1 & 10 & 50 & \\
7 & 4 & - & 10 & - & \\
8 & 3 & - & 10 & - & \\
9 & 2 & - & 10 & - & \\
10 & 1 & - & 10 & & 1140 \\
Jumlah & & & & 76 & \\
Rata-rata & & & & $93,0 \%$ & \\
Persentasse ketuntasan belajar & & &
\end{tabular}

Berdasarkan data yang disajikan pada Tabel 5, diketahui bahwa nilai ratarata kelas yang diperoleh di akhir siklus II adalah 76. Nilai ini lebih besar dibandingkan dengan nilai rata-rata kelas diakhir Siklus I yaitu 70. Peningkatan nilai rata-rata kelas sekitar 6 point jika dibandingkan dengan nilai rata-rata kelas pada siklus I. Selain itu, informasi lain yang diperoleh dari Tabel 6 adalah capaian ketuntasan belajar siswa. Ketuntasan belajar siswa pada akhir siklus II adalah 93,0\%. Hasil yang diperoleh ini juga menunjukkan terjadinya peningkatan capaian ketuntasan belajar siswa dibandingkan dengan ketuntasan belajar 
siswa setelah pelaksanaan tindakan siklus I yaitu sebesar 80,0\%. Peningkatan yang terjadi sebesar $13,0 \%$. Berdasarkan hasil tersebut, dapat disimpulkan bahwa pemanfaatan media pembelajaran berupa kartu pasangan warna berhasil meningkatkan hasil belajar siswa dalam pengurangan bilangan bulat: (1) pengurangan bilangan bulat positf dengan bilangan bulat positif, (2) pengurangan bilangan bulat positif dengan bilangan bulat negatif, (3) pengurangan bilangan bulat negatif dengan bilagan bulat positif, dan (4) pengurangan bilangan bulat negatif dengan bilangan bulat negatif.

Keempat, Refleksi. Mengingat tindakan siklus II telah mengalami kemajuan yang cukup signifikan, baik di segi proses maupun di segi hasil maka peneliti memutuskan untuk menghentikan tindakan pada siklus II. Dengan demikian, penelitian tindakan kelas dianggap selesai.

\section{Analisis Peningkatan Hasil Belajar Siswa}

Berdasarkan hasil pengamatan, terdapat perubahan iklim belajar dari siklus pratindakan ke siklus I dan siklus II yang ditunjukkan dengan perbaikan di berbagai aspek kegiatan guru maupun siswa. Perubahan ini berpengaruh pada meningkatnya nilai atau prestasi belajar siswa. Hal ini disebabkan karena perlakuan tindakan pada masing-masing siklus berbeda-beda. Tindakan Siklus 1 merupakan perbaikan dari hasil tes penjajakan. Demikian juga dengan tindakan siklus II yang merupakan perbaikan dari Siklus I. Dengan kata lain, setiap tindakan memberikan alternatif dari kekurangan dan kelemahan pada siklus sebelumnya. Untuk memudahkan memahami peningkatan hasil belajar siswa dari setiap siklus, peneliti merangkum hasil belajar siswa pada Tabel 6 .

Tabel 6 Rekapitulasi hasil belajar siswa pada setiap Siklus

\begin{tabular}{cccccc}
\hline \multirow{2}{*}{ No } & \multirow{2}{*}{ Siklus } & \multicolumn{2}{c}{ Rata-rata kelas } & \multicolumn{2}{c}{ Ketuntasan Belajar } \\
& & Angka & Peningkatan & Angka & Peningkatan \\
\hline 1 & Pratindakan & 44 & - & $33,3 \%$ & - \\
2 & Tindakan I & 70 & 26 point & $80,0 \%$ & $46,7 \%$ \\
3 & Tindakan II & 76 & 6 point & $93,0 \%$ & $13,0 \%$ \\
\hline
\end{tabular}

Berdasarkan data yang disajikan pada Tabel 6, diketahui bahwa nilai ratarata kelas yang diperoleh di akhir siklus II adalah 76. Nilai ini lebih besar dibandingkan dengan nilai rata-rata kelas di akhir Siklus I yaitu 70 dan saat tes penjajakan (pratindakan) yaitu 44. Peningkatan nilai rata-rata kelas sekitar 6 point jika dibandingkan dengan nilai ratarata kelas pada siklus I dan 32 point jika dibandingkan dengan hasil belajar siswa saat pratindakan.

Tindakan yang diberikan tidak hanya berdampak pada peningkatan nilai rata-rata kelas saja tetapi juga berdampak pada angka ketuntasan belajar. Ketuntasan belajar siswa pada akhir siklus II adalah 93,0\%. Hasil yang diperoleh ini juga menunjukkan terjadinya peningkatan capaian ketuntasan belajar siswa dibandingkan dengan ketuntasan belajar siswa setelah pelaksanaan tindakan siklus I yaitu sebesar $80,0 \%$ dan pratindakan yaitu sebesar $33,3 \%$.. Peningkatan yang terjadi sebesar $13,0 \%$ jika dibandingkan dengan ketuntasan belajar siswa pada siklus I dan $59,7 \%$ jika dibandingkan dengan ketuntasan belajar saat tes penjajakan (pratindakan).

Berdasarkan hasil penelitian, dapat disimpulkan bahwa pemanfaatan media pembelajaran berupa kartu pasangan warna berhasil meningkatkan hasil belajar siswa dalam penjumlahan dan pengurangan bilangan bulat, yaitu:penjumlahan dan pengurangan bilangan bulat positf dengan 
bilangan bulat positif,penjumlahan dan pengurangan bilangan bulat positif dengan bilangan bulat negatif,penjumlahan dan pengurangan bilangan bulat negatif dengan bilagan bulat positif, danpenjumlahan dan pengurangan bilangan bulat negatif dengan bilangan bulat negatif. Hasil yang diperoleh ini menguatkan hasil penelitian yang telah dilakukan sebelumnya bahwa penggunaan media dapat meningkatkan hasil belajar siswa dalam penjumlahan dan pengurangan bilangan bulat (Farid, 2016; Estiningsih, 2016; Setiowati, 2016; Zurismiati, 2016; Iksanudin, 2012; Suhardi, 2012; Rejeki, 2011; Anggraheni, 2010; Purwanti, 2010)

\section{Tanggapan Siswa terhadap Penggunaan Media}

Keberhasilan tindakan yang diberikan baik dari segi proses dan segi hasil tidak terlepas dari pengaruh psikologis siswa terhadap penggunaan kartu pasangan warna pada pembelajaran penjumlahan dan pengurangan bilangan bulat. Peneliti menyebarkan lembar angket untuk mengetahui tanggapan siswa terhadap penggunaan kartu pasangan warna dalam penyajian pembelajaran penjumlahan dan pengurangan bilangan bulat. Tanggapan siswa mengenai media yang digunakan dalam penelitian ini disajikan pada Tabel 7.

Tabel 7 Tanggapan siswa terhadap penggunaan kartu pasangan warnadalam penyajian pembelajaran penjumlahan dan pengurangan bilangan bulat

\begin{tabular}{|c|c|c|c|c|}
\hline \multirow{2}{*}{ No } & \multirow{2}{*}{ Tanggapan Siswa } & \multicolumn{2}{|c|}{ Jawaban Siswa } & \multirow{2}{*}{ Total } \\
\hline & & $\mathrm{Ya}$ & Tidak & \\
\hline 1 & Mudah memahami pelajaran & $\begin{array}{c}12 \\
(80,0 \%)\end{array}$ & $\begin{array}{c}3 \\
(20,0 \%)\end{array}$ & $15(100 \%)$ \\
\hline 2 & $\begin{array}{l}\text { Senang belajar matematika dengan } \\
\text { media kartu pasangan warna }\end{array}$ & $\begin{array}{c}15 \\
(100,0 \%)\end{array}$ & $\begin{array}{c}0 \\
(0,0 \%)\end{array}$ & $15(100 \%)$ \\
\hline 3 & $\begin{array}{l}\text { Bersemangat mengerjakan tugas yang } \\
\text { diberikan guru. }\end{array}$ & $\begin{array}{c}15 \\
(100,0 \%)\end{array}$ & $\begin{array}{c}0 \\
(0,0 \%)\end{array}$ & $15(100 \%)$ \\
\hline 4 & Berani tampil didepan kelas & $\begin{array}{c}11 \\
(73,3 \%) \\
\end{array}$ & $\begin{array}{c}4 \\
(26,7 \%) \\
\end{array}$ & $15(100 \%)$ \\
\hline
\end{tabular}

Hasil yang disajikan pada Tabel 7 menunjukkan bahwa dua belas dari lima belas siswa menganggap media kartu pasangan warna memudahkan siswa untuk memahami materi penjumlahan dan pengurangan bilangan bulat. Hasil ini mendukung pernyataan Arsyad (2009) yang mengemukakan bahwa salah satu fungsi media dalam kegiatan pembelajaran adalah untuk memperjelas penyajian pesan yang disampaikan oleh pendidik. Penggunaan kartu pasangan warna membantu guru untuk memudahkan menjelaskan konsep dari penjumlahan dan pengurangan bilangan bulat. Selain membantu guru, penggunaan kartu pasangan warna juga membantu siswa dalam memahami materi. Materi yang diajarkan lebih konkrit sehingga mudah diterima oleh siswa.

Data yang disajikan pada Tabel 7 juga menginformasikan bahwa siswa senang belajar matematika dengan menggunakan media kartu pasangan warna. Kartu pasangan warna memudahkan siswa dalam memahami konsep penjumlahan dan pengurangan bilangan bulat. Pemahaman konsep membantu siswa dalam mengerjakan tugas yang diberikan oleh guru. Kemampuan siswa dalam memahami konsep membantu siswa dalam mengatasi kesulitan belajar, karena tidak adanya kemampuan dan keterampilan dasar yang dimiliki seorang individu merupakan faktor internal yang merupakan penyebab dari munculnya 
kesulitan belajar (Irham dan Wiyani, 2016). Pemahaman konsep memudahkan siswa dalam mengerjakan tugas yang diberikan oleh guru. Keberhasilan siswa dalam mengerjakan tugas dimanifestasikan dalam wujud rasa senang untuk mengikuti kegiatan belajar matematika yang awalnya dinilai sulit. Rasa senang ini juga mendorong semangat siswa untuk mengerjakan tugas yang diberikan oleh guru. Kemampuan siswa dalam mengerjakan soal yang diberikan juga akan mendorong lahirnya keberanian siswa untuk tampil di depan kelas. Dengan demikian, siswa merespon positif penggunaan kartu pasangan warna dalam pembelajaran matematika.

\section{SIMPULAN}

Temuan dalam penelitian tindakan kelas yang dilakukan dalam dua siklus (siklus I dan siklus II) ini adalah media pembelajaran yaitu penggunaan kartu pasangan warna dapat digunakan untuk meningkatkan hasil belajar siswa kelas $\mathrm{V}$ SDN. No. 040/XI Koto Limau Manis. Setelah diberikan tindakan, nilai rata-rata kelas dan ketuntasan belajar siswa meningkat jika dibandingkan dengan hasil belajar siswa sebelum diberikan tindakan. Siswa juga menanggapi positif penggunaan media kartu pasangan warna dalam kegiaatn pembelajaran matematika. Media yang digunakan memudahkan siswa memahami pelajaran, membuat siswa merasa senang dan bersemangat untuk belajar, serta meningkatkan keberanian siswa untuk tampil di depan kelas.

Dalam pengembangan proses pembelajaran, guru hendaknya berperan aktif untuk mencari alternatif baru dalam mengembangkan media, metode dan teknik mengajar dalam upaya mengadakan pembaharuan dibidang profesi guru. Untuk menyampaikan pesan dari kongkrit ke yang abstrak, guru hendaknya menggunakan media, karena jika siswa hanya mendengarkan ia akan mudah lupa dan sebaliknya jika ia melakukan maka ia akan ingat lebih lama. Selain itu, untuk penelitian serupa hendaknya dilakukan perbaikan agar diperoleh hasil yang lebih baik.

\section{DAFTAR PUSTAKA}

Anggraheni, B. B. 2010. Peningkatan kemampuan menghitung penjumlahan dan pengurangan bilangan bulat melalui media manicmanik pada siswa kelas IV SDN Balangan Teras Boyolali tahun pelajaran 2009/2010 [Skripsi]. Surakarta: Fakultas Keguruan dan Ilmu pendidikan, Universitas Sebelas Maret.

Arsyad, A. 2009. Alat peraga Pembelajaran. Jakarta: PT Raja Grafindo Persada.

Estiningsih, S. 2016. Upaya meningkatkan keaktifan belajar matematika materi penjumlahan dan pengurangan bilangan bulat menggunakan model Team Assistied Individualization kolaborasi dengan media keping warna pada siswa kelas IV SD Negeri 02 Sewurejo Kecamatan Mojogedang Kabupaten Karanganyar tahun pelajaran 2012/2016 [Skripsi]. Surakarta: Fakultas Keguruan dan Ilmu Pendidikan, Universitas Muhammadiyah Surakarta.

Farid, M. 2016. Peningkatan Hasil Belajar Operasi Hitung Bilangan Bulat Melalui Model Pembelajaran Matematika Realistik Berbasis Teori Belajar Bruner Pada Siswa Kelas IV SD Negeri Kaligayam 02 Kabupaten Tegal [Skripsi]. Semarang: Fakultas Ilmu Pendidikan, Universitas Negeri Semarang.

Ikhsanudin. 2012. Penerapan Metode bermain Peran untuk Meningkatkan prestasi Belajar operasi Bilangan Bulat Mata Pelajaran Matematika kelas V MI MAARIF 01 Layangsari 2011-2012 [Skripsi]. Yogyakarta: Fakultas Tarbiyah dan Keguruan, 
Universitas Islam negeri Sunan kalijaga.

Irham, M., \& Wiyani, N. A. 2016. Psikologi Pendidikan: Teori dan Aplikasi dalam Proses Pembelajaran. Yogyakarta: Ar Ruzz Media.

Purwanti, D. N. 2010. Peningkatan pemahaman konsep operasi hitung penjumlahan dan pengurangan bilangan bulat melalui pendekatan tari bambu (PTK Pembelajaran Matematika Di Kelas VII Semester Gasal SMP Negeri I Brang Rea Taliwang Sumbawa Nusa Tenggara Barat Tahun Ajaran 2009/2010) [Skripsi]. Surakarta: Fakultas Keguruan dan Ilmu Pendidikan, Universitas Muhammadiyah Surakarta.

Raharjo, M, \& Sumardi. 2010. Pembelajaran Penjumlahan dan Pengurangan Bilangan Bulat di SD. Sa'diyah C, Editor. Yogyakarta: Pusat Pengembangan dan Pemberdayaan Pendidik dan Tenaga Kependidikan Matematika, Direktorat Jenderal Peningkatan Mutu Pendidik dan Tenaga Kependidikan, Kementerian Pendidikan Nasional.

Rejeki, S. 2011. Penggunaan media manikmanik untuk meningkatkan kemampuan menghitung pengurangan bilangan bulat pada siswa kelas IV SDN Nglebak 03 Tawangmangu tahun pelajaran 2010/2011 [skripsi]. Surakarta: Fakultas Keguruan dan Ilmu Pendidikan, Universitas Sebelas Maret.

Setiowati, Y. 2016. Peningkatan Aktivitas dan Hasil Belajar Matematika Materi Penjumlahan dan Pengurangan Bilangan Bulat dengan Metode Buzz. Group Disertai Permainan Monopoli pada Siswa Kelas IVA SDN Ajung 03 Jember [Skripsi]. Jember: Fakultas keguruan dan Ilmu Pendidikan, Universitas Jember.
Suhardi. 2012. Peningkatan pemahaman konsep penjumlahan dan pengurangan pada bilangan bulat dengan menggunakan media mistar bilangan kelas V A SDN Guwosari Kabupaten Bantul [skripsi]. Yogyakarta: Fakultas Ilmu Pendidikan, Universitas Negeri Yogyakarta.

Sukayati, \& Suharjana, A. 2009. Pemanfaatan Media Matematika dalam Pembelajaran di SD. Wibawa $\mathrm{AD}$, Editor. Yogyakarta: Pusat Pengembangan dan Pemberdayaan Pendidik dan Tenaga Kependidikan Matematika, Direktorat Jenderal Peningkatan Mutu Pendidik dan Tenaga Kependidikan, Kementerian Pendidikan Nasional.

Supardi. 2012. Pengaruh pembelajaran matematika realistic terhadap hasil belajar matematika ditinjau dari motivasi belajar. Cakrawala Pendidikan. XXXI (2): 244-255.

Zurismiati. 2016. Upaya Meningkatkan Pemahaman Siswa pada Operasi Penjumlahan dan Pengurangan Bilangan Bulat Melalui Metode Demonstrasi dengan menggunakan Media [skripsi]. Jakarta: Fakultas Ilmu Tarbiyah dan keguruan, Universitas Islam Negeri Syarif Hidayatullah. 